as they present aspects of biochemistry and cellfunctioning in a relatively simple form free from many of the complications encountered with higher organisms. One such problem is the activation of enzymes which is sometimes produced by the presence of living cells. The author observed, for instance, that certain kinds of starch granules, capable of resisting indefinitely the action of a highly diastatic liquid in which they were immersed, were readily attacked by the diastase after a trace of yeast had been added. Possibly the explanation is to be sought in the reversible nature of enzyme action and the continuous removal of certain products by the yeast. The subject may perhaps throw some light on the influence of "vitamines" on animal nutrition. The allied problem of symbiosis is exemplified in a relatively simple form by the "amyloprocess" employed in certain distilleries at Seclin, in France. In this process the sterilised amylaceous material is saccharified and converted into alcohol and carbon dioxide in one operation by the joint action of a mould fungus which produces diastase, and a yeast which effects fermentation. Another subject which should be of interest to the physiologist relates to the quantitative relation between the reproduction of yeast cells and the supply of oxygen available. The author found that when cells are sparsely distributed through a nutrient liquid the oxygen initially dissolved in the liquid is rapidly absorbed by the cells, and the "oxygen-charge" per cell thus taken up determines the reproductive capacity of the yeast, provided no further oxygen is available. The author gives further examples of the extension of scientific knowledge resulting from the study of brewing problems, and discusses at length some of the more technical matters which still await solution.

\section{THE PLAINS OF NORTHERN INDIA AND THEIR RELATIONSHIP TO THE HIMALAYA MOUNTAINS.1}

A HUNDRED years ago the accepted idea was A that mountain ranges were due to the upward pressure of liquid lava, and that their elevation had been caused by volcanic forces. But when geologists began to study the structure of rocks, they found that mountains had suffered from horizontal compression, which was evident from the folding of strata. This discovery led to the idea that mountains had been elevated, not by vertical forces, but by horizontal forces, which squeezed the rock upward. The wrinkling of the earth's crust into mountains by horizontal forces was explained by the cooling of the earth; this is the well-known contraction theory; the earth's interior is held to cool and to contract, and the outer crust is supposed to get too large for the shrinking core and to wrinkle.

About 1860 the observations of the plumb-line brought to light a most important and totally unexpected fact, namely, that the Himalaya-were not exercising an attraction at all commensurate with their bulk.

The plumb-line was observed at Kaliana, 6o miles from the foot of the mountains; the observers found that the Himalaya were exercising no appreciable attraction. By the theory of gravitation the plumbline ought to be deflected at Kaliana 58 seconds towards the hills. It is not deflected at all; it hangs vertically. This discovery was the first contribution made by geodesy to the study of mountains. The discovery was this, that the Himalaya behaved as if they had no mass, as if they were an empty eggshell;

1 Abridged from an address to the Indian Science Congress at Lucknow on January 13 by the president, Sir Sidnev Burrard, F.R.S. No. 2436 , VOL. 97] they seemed to be made of rock, and yet they exercised no more attraction than air. From the Kaliana observations Pratt deduced his famous theory of mountain compensation; he explained the Kaliana mystery by assuming that the rocks underlying the mountains must be lighter and less dense than those underlying plains and oceans. The visible mountain masses, he said, are compensated by deficiencies of rock underneath them. This is the theory of mountain compensation. The compensation of the Himalaya is not believed now to be exactly complete and perfect; they seem to be compensated to the extent of about 80 per cent.; their total resultant mass is thus about one-fifth only of their visible mass standing above sea-level. The discovery of molintain compensation struck a blow at all theories which attributed the elevation of mountains to any additional masses that had been pushed in from the sides. The elevation of mountains by subterranean lava squeezed in from the side had to be rejected because it gave to mountains additional mass; the wrinkling of the earth's surface by lateral horizontal forces had to be rejected because it gave to mountains additional mass pushed in from the sides. As the Himalaya possess only one-fifth of their apparent visible mass, I am led to suggest that the principal cause of their elevation has been the vertical expansion of the rocks underlying them, vertical expansion due to physical or chemical change.

\section{Mountains Originate at Great Depths.}

A very important work has been that of Mr. Hayford, who has recently discussed the results of the plumb-line at a large number of stations in America. $\mathrm{He}$ has confirmed Pratt. Hayford has investigated the depth to which the deficiency of density underlying mountains goes down, and he has found that that depth is between 60 and 90 miles. That is to say, he has shown that the depth of subterranean compensation is very great compared with the height of mountains. The discovery that mountains originate from the great depth of 60 to 90 miles is the second important contribution of geodesy to this study. The first was compensation, the second is great depth.

Southerly Deflections Prevail over the Ganges Plains.

Now let me tell you of the third discovery due to this plumb-line. The survey found that at 60 miles from the hills this plumb-line hung vertically, and Pratt deduced the theory of mountain compensation. But when the survey began to extend their operations, a new phenomenon came to light, which caused great surprise. All over northern India at distances exceed. ing 70 miles from the hills, this plumb-line was found to hang decisively away from the mountains; here at Lucknow it is deflected 9 seconds to the south. If the Himalaya were simply compensated, this plumb-line should be hanging at Lucknow exactly vertical; if the mountains were not compensated, it should be deflected here about 50 seconds towards the north. But it is deflected 9 seconds towards the south. The observers were astonished to find that at places in sight of Himalayan peaks the plumb-line turned away from the mountain mass; that at Amritsar, in sight of the Dhauladhar snows, it was deflected towards the low Punjab plains; at Bombay it was deflected seawards away from the Western Ghats; on the east coast of India it was deflected seawards away from the Eastern Ghats.

The new lesson to be learnt from the plumb-line is this: a hidden subterranean channel of deficient density must be skirting the mountains of India. Here in North India is a wide zone of deficient density, of crustal attenuation; it is the presence of this zone of deficiency that accounts for the southerly deflection 
of the plumb-line. What is the meaning of this zone? How has it come into existence?

If you look at this section the earth's crust in these outer Himalaya has been compressed laterally: of this there is no doubt. The area between the snowy range and the foothills is a zone of crustal compression. And I suggest for your consideration that the Gangetic trough, this zone of deficiency, is a zone of tension in the crust. The crust has been stretched here and attenuated. Here you have compression, and alongside is the tension. The tension is the complement of the compression. I have pointed out that the Himalaya mountains are largely, but not completely, compensated by their underlying deficiencies of density; their compensation is, however, rendered complete by the presence of the Ganges trough; if the Himalayan compression and the Gangetic tension are considered together, it will be found that there is no extra mass.

\section{Hypothesis of a Rift.}

I showed you on the evidence of the plumb-line that the Gangetic trough was a zone of crustal attenuation, a zone in which the earth's crust was deficient in density. I then took one step forward and suggested that it was a zone of tension. I will now take another step forward and suggest to you that there has occurred an actual opening in the subcrust, and that the outer crust has fallen in owing to the failure of its foundations. I suggest that the Ganges plains cover a great rift in the earth's crust.

The earth is a cooling globe; an increase of temperature occurs as we descend into mines; and this temperature gradient is a proof that the earth is losing heat by conduction outwards. The discovery of radium has not affected the argument.

The rock composing the crust and subcrust is, however, a bad conductor, and the interior of the earth will not shrink away from its crust, as has been assumed in the contraction theory. The inner core of the earth is, in fact, not losing heat appreciably. The outs- ehell was the first to lose its heat, then the shell below it, and the subcrust is now losing its heat more quickly than the interior core. As the outer shells coritract from cooling they become too small for the core, and they crack. Supposing we had here a great globe of rock, red-hot throughout; how would it conl? Can you imagine it cooling in such a way that the core became too small for the outer shell, and the outer shell became wrinkled? No; the outer shell would cool first, and would crack.

The outer shell of the earth was the first to crack millions of years ago; now a lower shell, the subcrustal shell, is cracking. When a crack occurs in the subcrust, parts of the upper crust fall in.

You will see that this Indus-Ganges trough has the appearance of a crack. And there are reasons for believing that these Himalaya have been split off from this ancient table-land, and have been moved northwards and crumpled up into mountains.

From the Bay of Bengal to the Mediterranean.

Geologists have discovered that the ancient tableland of the Vindhyas and Deccan is a remnant of a much greater table-land that in very early ages included Africa and Arabia. Africa and Arabia and the Deccan table-land are, in fact, fragments of one extensive and ancient continent.

To the west of Karachi we see the Persian Gulf and the plains of the Tigris-Euphrates. The plains of the Tigris-Euphrates are very similar to those of the Ganges: they consist of mud, sand, and sediment bying in a long trough between the ancient table-land of Arabia and the mountains of Persia.

Further west we find the Euphrates trough is con- tinued by the Mediterranean Sea, and the Mediter ranean is bounded on the north by the Taurus moun tains, by the Balkans, Carpathians, Apennines, and Alps.

Throughout the whole distance from Calcutta to Sicily we see that the old table-land, India-Arabia Africa, is bounded on the north by a long trough, and that this trough is, in its turn, bounded by the younger mountain ranges from the Himalaya to the Alps. Geologists have discovered that all these mount tain ranges were elevated in the same era; they are all of the same age.

I submit for your consideration that the Ganges, Indus-Euphrates-Mediterranean trough is an indica, tion at the earth's surface of a rift in the subcrust.

The whole zone from Java to Sicily has been visitec by earthquakes throughout the historic period. And the recent earthquakes in Shillong, Dharmsala, anc Messina show that seismic activity is continuing ir our time. This is, in fact, one of the zones of the earth along which earthquakes occur most frequently.

\section{The Bombay Coast.}

I must now invite your attention to the Bombay coast. From the Tapti to Cape Comorin runs the range of mountains known as the Western Ghats. This range is parallel to the coast of India and about 40 miles inland; it rises suddenly with a steep scarp. The strata are almost as horizontal as when first laid down; they have never been compressed or folded.

The survey has observed the plumb-line at different points along this coast; it is always deffected strongly towards the sea. To the west of Bombay and Mangalore there is the deep sea; and to the east there is a massive range more than $4000 \mathrm{ft}$. high; yet the plumbline will hang seawards. If the Western Ghats possessed the mass which they appear to possess, and which the Suess school ascribes to them, then the Bombay plumb-line should be deflected i5 seconds towards them. If, on the other hand, the Western Ghats are compensated by deficiencies of mass underlying them in accordance with the compensation theories of Pratt and Hayford, then the plumb-line should hang vertically at Bombay. But the plumbline takes neither of these courses; it hangs towards the sea. We have been puzzled for years by the plumb-line at Bombay; we used to think that the rock under the ocean must be so dense and heavy that it was able to pull the plumb-lines towards the sea. Major Cowie, however, observed in the south cf Kathiawar, and found that the plumb-line here had a strong landward deflection. The seaward deflections occur throughout the Bombay coast, but not round Kathiawar. It is only quite recently that we have realised we have at Bombay the same phenomenon as at Lucknow.

In northern India the plumb-line will persist in hanging away from the visible mountains, and at Bombay it takes the same course, and when I consider its constant seaward deflection I can only suggest to you that a crack in the subcrust has extended from Cape Comorin to Cambay, and that as this crack has occurred the Western Ghats have been elevated. The crack has been filled by masses of fallen rock and by alluvial deposits brought down by rivers.

Geologists have shown that this range consists, from latitude $20^{\circ}$ to $16^{\circ}$, of the lavas of the Deccan, comparatively recent rocks, whilst from latitude $16^{\circ}$ to $8^{\circ}$ the range consists of ancient metamorphic rocks. The rocks of the northern part of the range are of a different age and structure and origin from those of the southern.

Nevertheless, geodesists contend that this is one and NO. 2436 , VOL. 97] 
the same range; the rocks composing it have had nothing to do with its elevation. The Western Ghats have been elevated, after the Deccan lavas had become solidified, into surface rocks. Their elevation took place in the Tertiary age.

The Depth of the Gangetic Rift.

In consiclering the depth of the Gangetic rift we must appeal, first, to geodesy, and then to seismology. Now geodesy tells us that the compensation of the Himalaya (i.e. the root of the Himalaya) extends downwards to a great depth. I regard the Gangetic plains and the Himalayan range to be the two parts of one whole; I believe that they have originated together, and if the depth of Himalayan compensation extends down to 60 miles, then I think that the Gangetic rift may extend down to that depth also.

Now let us turn to seismology; seismologists are able to form rough estimates of the depths of earthquakes. In the Dharmsala earthquake Middlemiss estimated its depth to be between 12 and 40 miles. Middlemiss's maximum value is not very different from the geodetic value.

It is an interesting question to consider whether a fissure in rocks could extend downwards to a great depth. From a place near the Indus in Kashmir it is possible to see a continuous wall of rock 4 miles in height, on the flank of Nanga Parbat. Mount Everest stands erect $5 \frac{1}{2}$ miles above sea-level; its summit stands firm and rigid in miles above the depths of the Bay of Bengal. We have, therefore, evidence that the materials of the crust are strong enough to admit of the continued existence of great differences in altitude.

But Mount Everest is standirg in air, whereas a crack in the subcrust becomes filled with rocks falling in and with fluid rock magma from below; and the walls of the crack thus get a support that Mount Everest does not possess. It seems to me quite possible that a crack such as I have described may have extended down to a depth of 60 miles by successive fractures at increasing depths, the opening being filled by falling material.

Internal Causes of Mountain Elevation.

I have shown you how zones of subsidence in the crust are bordered by mountains, and I have now to discuss the relationship of subsidence to elevation, of troughs to mountains. The Red Sea is a zone of fracture, and it is bordered on each side by a zone of elevation. But along the Bombay coast the zone of subsidence is bordered only on the one side by a zone of elevation. The suberustal crack from Surat to Cape Comorin has been accompanied by a vertical uplift of the Ghats, and I suzgest for your consideration that the vertical force which elevated the Ghats was the expansion of the underlying rock due to physical or chemical change.

Mr. Hayden informs me that the specific gravity of the rock composing the Neilgherries varies from 2.67 to 3.03 -that is, 14 per cent.-and that the rock of the Hazaribagh plateau varies from 2.5 to $3.1-24$ per cent.

The Western Ghats appear to have risen about $4000 \mathrm{ft}$. Now we know that the Western Ghats are largely compensated by underlying deficiency of density; if the compensation of the Western Ghats extends downwards to a depth of 60 miles, then an expansion of 2 per cent. would be more than sufficient to account for the elevation of the Ghats. Mr. Hayden finds variations of 14 and of 24 per cent. in the densities of surface rocks, and yet an expansion of only 2 per cent. would account for both the elevation and the compensation of the Ghats.

The heterogeneous rocks composing the earth's crust are continually undergoing changes of structure, known NO. 2436 , VOL. 97$]$ to geologists as metamorphism. At a depth of 30 miles the temperature is sufficiently high to melt all known rocks; but increase of pressure raises the melting point, and the increase of pressure underground may be sufficiently great to counteract the effects of the increase of temperature. So that at a depth of even 60 miles rocks may still be solid and rigid, as geodesy leads us to believe they are.

The main ranges of the Himalaya are composed of granite; this granite has protruded upwards from below. I suggest that the protrusion of granite is due to expansion of rocks in the subcrust. The great Himalayan range is 5 miles high, and the compensation of this range-that is, its underlying deficiency of density-is estimated to extend downwards to a depth of perhaps 75 miles. An underground expansion of 7 per cent. would be sufficient to account for the elevation of the Himalaya.

Many of the faults which intersect the Himalaya may, I think, be ascribed to the shearing which must have ensued when certain areas of the crust were forced vertically upwards by the metamcrphism of subcrustal rock. Many distortions of surtace strata may be ascribed to local variations in the vertical expansion of deep-seated rocks.

The peculiar sinuous curve of the northern Tibetan border, concave on the east, convex on the west, is reproduced in the north of Persia, and again in the Carpathians. The Persian ranges all have a trend from south-east to north-west, except that the Caspian subsidence seems to have pushed rudely in from the north and forced the northern range into a sinuous curve. It is significant that at the point of the Caspian push stands the peak of Demavend, the highest point in all Persia. Elevation is the companion of subsidence.

The conclusions which I have ventured to submit to this meeting may be summarised as follows :-

(I) The fundamental cause of both elevation and subsidence is the occurrence of a crack in the subcrust.

(2) Mountains are compensated by underlying deficiencies of matter.

(3) Mountains have risen out of the crust from a great depth, possibly 60 miles.

(a) Mountains owe their elevation mainly to the vertical expansion of subjacent rock.

I have now had the great privilege of placing certain problems before you. My endeavour has been to point out to this congress, and especially to its younger members, the many scientific secrets that are lying hidden under the plains of northern India.

\section{UNIVERSITY AND EDUCATIONAL INTELLIGENCE.}

OxFORD.-No honorary degrees were conferred at this year's Encænia, but on June $29 \mathrm{Mr}$. Douglas W. Freshfield received the honorary degree of D.C.L. The Public Orator, in presenting Mr. Freshfield, laid especial stress on his advocacy of the claims of geography for full recognition among university studies. $\mathrm{He}$ spoke also of Mr. Freshfield's eminence as a mountaineer, of his personal devotion to the theory and practice of geographical science, and of his achievements as a man of letters.

SHEFFIELD. - In connection with the new department of glass technology the University has instituted a diploma in the subject. The course of study will cover three years, but candidates who have spent at least two years in the glass industry may be exempted from attendance in the first year's course under certain conditions. The last two years' study will be devoted almost entirely to the chemistry, physics. and 